\title{
PENGARUH KECERDASAN EMOSIONAL DAN KOMITMEN ORGANISASIONAL TERHADAP KINERJA KARYAWAN BAGIAN BUSANA ROXY SQUARE MALL JEMBER DENGAN ORGANIZATIONAL CITIZENSHIP BEHAVIOR (OCB) SEBAGAI VARIABEL INTERVENING
}

\author{
Adi Putra ${ }^{1}$ \\ Email: adi.putrha.1998@gmail.com \\ Dewi Prihatini ${ }^{2}$ \\ Email: dewi.prihatini@unej.ac.id \\ Agus Priyono $^{3}$ \\ Email: agus.priyono@unej.ac.id
}

\begin{abstract}
This study aims to determine the influence of emotional intellegence and organizational commitment on the employee performance fashion department in Roxy Square Mall Jember with organizational citizenship behavior (OCB) as intervening. The population in this study were all employees working at fasion department Roxy Square Mall Jember branch as much as 210 employees and the sample used was 138 respondents. The sampling technique uses probality sampling with simple random sampling method. The research model was tested by using the path analysis.

The results of this study showed that the emotional intelligence and organizational commitment had a positive effect on Organizational Citizenship Behavior (OCB). The emotional intelligence, organizational commitment and Organizational Citizenship Behavior (OCB) had a positive effect on the employee performance. Emotional intelligence and organizational commitment had an indirect effect on the employee performance through the Organizational Citizenship Behavior (OCB). When analyzed further, the percentage of direct effect was higher than the indirect effect, which showed that the mediating variable of Organizational Citizenship Behavior (OCB) had less effect on the employee performance.
\end{abstract}

\footnotetext{
1, Corresponding author: Jurusan Manajemen, Fakultas Ekonomi dan Bisnis, Universitas Jember, Jalan Kalimantan No. 37, Kampus Tegalboto, Kecamatan Sumbersari, Jember, 68121, Jawa Timur, Indonesia.

2,3 Jurusan Manajemen, Fakultas Ekonomi dan Bisnis, Universitas Jember, Jalan Kalimantan No. 37, Kampus Tegalboto, Kecamatan Sumbersari, Jember, 68121, Jawa Timur, Indonesia.
} 


\section{Keywords: Emotional Intelligence, Organizational Commitment,} Organizational Citizenship Behavior (OCB), Employee Performance

\section{PENDAHULUAN}

Globalisasi memaksa perusahaan harus berkembang untuk tetap eksis dalam dinamika kebutuhan masyarakat. Terlebih pada perusahaan yang bergerak dibidang perdagangan, dituntut untuk senantiasa memberi daya kreatif yang tinggi dalam memenuhi kebutuhan masyarakat. Perkembangan perusahan yang bergerak di bidang perdagangan harus diiringi dengan kualitas dari sumberdaya manusia yang dimiliki. Hal ini sesuai dengan harapan Roxy Square Mall Jember yang menginginkan kinerja dari tenaga kerjanya memiliki kualitas yang baik.

Roxy Square Mall Jember pada periode tiga tahun terakhir yakni tahun 2016, 2017, dan 2018, menurut pihak perusahaan ada kecenderungan stagnan dalam penjualan atau bahkan mengalami penurunan penjualan pada bagian busana, walaupun penurunan penjualan ini tidak secara signifikan. Menurut pihak manajemen perusahaan fenomena tersebut diakibatkan adanya faktor eksternal baik dari sisi perusahaan maupun dari sisi sumber daya manusia. Adapun faktor eksternal berupa persaingan usaha di kawasan Jember sudah semakin ketat. Selain itu faktor yang mempengaruhi kinerja seseorang berasal dari internal manusianya, diantaranya faktor internal yakni meliputi kecerdasan emosional, komitmen organisasional dan Organization Citizenship Behavior (OCB) yang dimiliki oleh setiap karyawan.

Goleman (2015, 45) mendefinisikan kecerdasan emosional sebagai kemampuan dalam menggali perasaan diri dan perasaan orang lain, memotivasi diri serta mengelola emosi dengan baik pada diri sendiri dan hubungannya dengan orang lain. Sejauh mana seseorang dapat mengenali dirinya sendiri dengan mengerti kekurangan serta kelebihannya. Biasanya seseorang yang mempunyai kecerdasan emosional yang baik dia dapat mengambil keputusan dengan tepat dan tegas. Karyawan bagian busana Roxy Square Mall Jember erat hubungannya dengan konsumen, sehingga kecerdasan emosional para karyawan sangat diperhatikan dalam proses kinerja karyawan. Namun observasi yang dilakukan masih terdapat karyawan yang bersikap malas terhadap pelayanan kepada konsumen, hal ini terlihat dari feedback maupun raut wajah yang diberikan. Penelitian yang dilakukan oleh Sumyarsih et al. (2012), Fitriastuti (2013), Marga (2016), Pratama (2016), Amalia dan Purnawa (2016), serta Ardiansyah dan Sulistiyowati (2017) menyimpulkan bahwa kecerdasan emosional berpengaruh positif dan signifikan terhadap kinerja karyawan.

Hal yang perlu diperhatikan untuk mengetahui faktor internal yang mempengaruhi kinerja karyawan adalah komitmen organisasional. Menurut Robbins dan Judge $(2016,110)$ memperjelas dengan mendefinisikan komitmen organisasional sebagai suatu keadaan seorang pegawai atau karyawan yang memiliki sikap memihak kepada organisasi tertentu dan tujuan-tujuannya, serta berniat untuk memelihara keanggotaan dalam organisasi tersebut. Pihak manajemen Roxy Square Mall Jember menuturkan bahwa komitmen organisasional karyawan bagian busana sudah baik, dibuktikan dengan tingkat absensi dan turnover menunjukkan skala rendah. Penelitian yang dilakukan oleh Jatmiko et al. (2015), Respatiningsih dan Sudirjo (2015), Putrana et al. (2016), Damaryanthi dan Dewi (2016), Sapitri (2016), dan Akbar et al. (2017) menyatakan bahwa komitmen organisasional berpengaruh 
positif terhadap kinerja karyawan. Pernyataan tersebut dikarenakan karyawan yang memiliki komitmen organisasional yang tinggi terhadap tempat ia bekerja, akan menunjukkan kinerja yang mengalami peningkatan (Rochayatun dan Setiawan 2020).

Perubahan dalam sistem kerja maupun lingkungan kerja yang dilakukan terus menerus pada perusahaan akan menimbulkan perilaku yang berdampak positif maupun negatif, salah satunya perilaku Organizational Citizenship Behavior (OCB). Dari berbagai literatur terdahulu, didapatkan hasil Organizational Citizenship Behavior (OCB) berhubungan dengan hasil kinerja organisasi seperti kualitas pelayanan, komitmen organisasi, keterlibatan karyawan, dan leader-member exchange (Kurniawan 2015, 96). Organizational Citizenship Behavior (OCB) merupakan perilaku individu yang ekstra, yang tidak secara langsung atau eksplisit dapat dikenali dalam suatu sistem kerja yang formal, dan yang secara agregat mampu meningkatkan efektivitas fungsi suatu organisasi sehingga Organizational Citizenship Behavior (OCB) sangat penting dalam kelangsungan hidup organisasi. Garay $(2006,34)$ menjelaskan bahwa OCB merupakan perilaku sukarela dari seorang pekerja untuk mau melakukan tugas atau pekerjaan di luar tanggung jawab atau kewajibannya demi kemajuan atau keuntungan organisasinya Karakteristik perilaku yang beraneka ragam menuntut karyawan bagian busana untuk senantiasa memberikan pelayanan dengan baik, yang tidak hanya bekerja sesuai dengan beban kerja saja, melainkan juga perlu daya ekstra dalam menghadapi perilaku konsumen. Namun fenomena yang terjadi masih terdapat sikap acuh karyawan terhadap teman kerja, terlebih pada hari-hari libur nasional dan hari-hari besar. Seperti tidak membantu temannya, walaupun pekerjaannya sudah selesai dan juga masih terdapat sikap tidak peduli ketika temannya meminta bantuan untuk mengambilkan size baju yang tidak sesuai dengan keinginan konsumen serta tidak peduli ketika teman meminta bantuan untuk merapikan baju-baju dan lain-lain. Penelitian yang dilakukan oleh Kimbal et al. (2015), Suzana (2017), Pristiwati dan Suharyono (2018) serta Ramadhan et al. (2018) menyimpulkan bahwa Organizational Citizenship Behavior (OCB) berpengaruh positif terhadap kinerja karyawan, dikarenakan karyawan yang memiliki sifat ini akan cenderung lebih ekstra dalam bekerja untuk perusahaan.

Berdasarkan fenomena yang terjadi di Roxy Square Mall Jember dan perbedaan objek penelitian terdahulu maka peneliti memiliki maksud dan tujuan untuk mengkaji mengenai pengaruh kecerdasan emosional dan komitmen organisasional terhadap kinerja karyawan bagian busana Roxy Square Mall Jember dengan Organizational Citizeship Behavior (OCB) sebagai variabel intervening.

\section{METODE PENELITIAN}

\subsection{Rancangan atau Desain Penelitian}

Berdasarkan latarbelakang dan rumusan masalah penelitian ini dapat dikategorikan sebagai penelitian penjelasan (explanatory research) karena penelitian ini bermaksud menjelaskan hubungan kausal (sebab-akibat) antar variabel melalui pengujian yang telah dirumuskan. Dalam penelitian ini menggunakan pendekatan kuantitatif yaitu data diukur menggunakan statistik. Populasi dalam penelitian ini adalah seluruh karyawan yang bekerja di bagian busana Roxy Square Mall Jember sebanyak 210 karyawan dan sampel yang digunakan sebanyak 138 responden. 
Teknik pengambilan sampel menggunakan probality sampling dengan metode simple random sampling.

\subsection{Jenis dan Sumber Data}

Jenis data dalam penelitian ini merupakan jenis data primer dan sekunder. Data primer adalah data yang berasal langsung dari sumber data yang dikumpulkan secara khusus dan berhubungan langsung dengan masalah penelitian yang akan diteliti. Data sekunder adalah data yang bersifat melengkapi data primer dan diperoleh dari pihak lain. Teknik pengumpulan data dalam penelitian ini dilakukan dengan menyebarkan kuesioner secara langsung kepada responden, studi pustaka, observasi dan wawancara. Pengukuran kuesioner pada penelitian ini menggunakan Skala Likert.

\subsection{Metode Analisis Data}

Teknik analisis data dilakukan dengan cara uji instrumen yang terdiri atas uji validitas dan reliabilitias, uji normalitas data, analisis jalur, uji asumsi klasik, uji hipotesis (uji t).

\subsubsection{Uji Validitas}

Uji validitas digunakan untuk mengukur sah atau valid tidaknya suatu kuesioner. Kuesioner dikatakan valid jika pertanyaan pada kuesioner mampu untuk mengungkapkan sesuatu yang akan diukur oleh kuesioner tersebut. Hasil uji validitas terhadap data dalam penelitian ini menunjukkan variabel kecerdasan emosional $\left(\mathrm{X}_{1}\right)$, komitmen organisasional $\left(\mathrm{X}_{2}\right)$, organizational citizenship behavior $(\mathrm{Z})$, dan kinerja karyawan $(Y)$ memiliki Nilai Signifikan $<0,05$ serta memiliki nilai $R_{h i t u n g}>$ $\mathrm{R}_{\text {tabel. }}$ Hal ini dapat disimpulkan bahwa seluruh item pertanyaan variabel penelitian ini dinyatakan valid.

\subsubsection{Uji Realibilitas}

Uji reliabilitas bertujuan untuk mengukur apakah suatu kuesioner memiliki tingkat konsistensi apabila kuesioner tersebut digunakan secara berulang. Pengukuran uji reliabilitas dalam penelitian ini menggunakan aplikasi SPSS versi 23. Uji reliabilitas dalam penelitian ini menggunakan cronbach's alpha. Suatu instrumen dapat dikatakan reliabel apabila cronbach's alpha lebih dari (>) 0,60. Hasil uji reliabilitas pada instrumen kuesioner dalam penelitian ini adalah sebagai berikut:

Tabel 1. Hasil Uji Reliabilitas

\begin{tabular}{lccc}
\hline \multicolumn{1}{c}{ Variabel } & $\begin{array}{c}\text { Cronbach's } \\
\text { Alpha }\end{array}$ & $\begin{array}{c}\boldsymbol{\alpha} \\
\text { Ketetapan }\end{array}$ & Keterangan \\
\hline Kecerdasan Emosional $\left(\mathrm{X}_{1}\right)$ & 0,652 & 0,60 & Reliabel \\
Komitmen Organisasional $\left(\mathrm{X}_{2}\right)$ & 0,616 & 0,60 & Reliabel \\
Organizational Citizenship Behavior $(\mathrm{Z})$ & 0,627 & 0,60 & Reliabel \\
Kinerja Karyawan $(\mathrm{Y})$ & 0,655 & 0,60 & Reliabel \\
\hline Sumber: diolah, 2019 & & &
\end{tabular}

Keseluruhan variabel dalam penelitian ini memiliki nilai Cronbach's Alpha $(\alpha)$ yang melebihi standar reliabilitas $(0,60)$ sehingga disimpulkan bahwa seluruh instrumen kuesioner variabel dalam penelitian ini dinyatakan andal (Reliable). 


\subsubsection{Uji Normalitas}

Uji normalitas digunakan untuk mengetahui apakah dalam sebuah model regresi, nilai residu dari regresi mempunyai distribusi yang normal. Pada penelitian ini peneliti memilih untuk menggunakan Kolmogrov-Smirvov Test dengan keyakinan $(\alpha)$ sebesar $5 \%$. Jika taraf signifikansi $(\alpha)>0,05$ maka data tersebut berdistribusi normal, jika taraf signifikansi $(\alpha)<0,05$ maka data tersebut berdistribusi tidak normal. Hasil pengolahan uji normalitas dapat dilihat sebagai berikut:

Tabel 2. Hasil Uji Normalitas Data

\begin{tabular}{lccc}
\hline \multicolumn{1}{c}{ Variabel } & $\begin{array}{c}\text { Nilai } \\
\text { Kolmogorov } \\
\text { Sumirnov }\end{array}$ & Sig. & Keterangan \\
\hline Kecerdasan Emosional (X1) & 1,228 & 0,098 & Berdistribusi normal \\
Komitmen Organisasional (X2) & 1,455 & 0,057 & Berdistribusi normal \\
Organizational Citizenship Behavior (Z) & 1,480 & 0,055 & Berdistribusi normal \\
Kinerja Karawan (Y) & 1,191 & 0,118 & Berdistribusi normal \\
\hline Sumber: diolah, 2019 & & &
\end{tabular}

Sumber: diolah, 2019

Nilai tersebut masing-masing lebih dari (>) taraf siginikansi yang telah ditentukan yaitu 0,05 atau $5 \%$. Dengan demikian dapat dinyatakan bahwa data dalam penelitian ini berdistribusi normal.

\subsubsection{Uji Multikolinieritas}

Uji multikolinearitas bertujuan untuk mengetahui apakah terjadi interkorelasi atau hubungan yang kuat antar variabel independent (variabel bebas). Model regresi yang baik ditandai dengan tidak adanya gejala multikolinearitas. Hasil uji multikolinearitas terhadap data pada penelitian ini dapat diringkas pada Tabel 3.

Tabel 3. Hasil Uji Multikolinearitas

\begin{tabular}{cccc}
\hline Model & \multicolumn{2}{c}{ Collinearity Statistics } & Keterangan \\
& Tolerance & VIF & \\
\hline $\mathrm{X} 1-\mathrm{Z}$ & 0,942 & 1,061 & tidak terjadi multikolinieritas \\
$\mathrm{X} 2-\mathrm{Z}$ & 0,942 & 1,061 & tidak terjadi multikolinieritas \\
$\mathrm{X} 1-\mathrm{Y}$ & 0,891 & 1,122 & tidak terjadi multikolinieritas \\
$\mathrm{X} 2-\mathrm{Y}$ & 0,914 & 1,095 & tidak terjadi multikolinieritas \\
$\mathrm{Z}-\mathrm{Y}$ & 0,896 & 1,116 & tidak terjadi multikolinieritas \\
\hline Sumber: diolah, 2019 & &
\end{tabular}

Dari hasil tersebut menunjukkan bahwa masing-masing model memiliki nilai tolerance lebih dari (>) 0,10 dan nilai VIF kurang dari $(<)$ 10,0 sehingga dapat disimpulkan semua model dalam penelitian ini tidak terjadi multikolinieritas. 


\subsubsection{Uji Heterokedastititas}

Uji Heterokedastisitas bertujuan untuk mengetahui ada tidaknya kesamaan varian dari nilai residual untuk semua pengamatan pada model regresi. Model regresi yang baik ditandai dengan tidak adanya gejala heterokedastisitas. Uji heteroskedastisitas dalam penelitian ini diukur dengan menggunakan pengujian Park. Apabila $\beta$ secara statistik signifikan, maka heteroskedastisitas terjadi pada data (Gujarati dan Porter, 2010:481). Dalam penelitian ini menggunakan $\alpha=5 \%$. Jika taraf signifikansi $(\alpha)>0,05$ maka tidak terjadi heteroskedastisitas. Hasil pengujian heteroskedastisitas dapat dilihat pada Tabel berikut:

1. Jalur satu $\mathrm{X}-\mathrm{Z}$

Tabel 4. Hasil Uji Glejser

\begin{tabular}{ccc}
\hline Variabel & Sig. & Keterangan \\
\hline Kecerdasan Emosional (X1) & 0,078 & Homokedastisitas \\
Komitmen Organisasional(X2) & 0,542 & Homokedastisitas \\
\hline
\end{tabular}

Sumber: diolah, 2019

Berdasarkan Tabel diatas dapat diketahui nilai signifikansi $(\alpha)$ masing- masing variabel memiliki nilai lebih dari (>) 0,05 sehingga dapat disimpulkan tidak terjadi heteroskedastisitas pada persamaan yang diuji.

2. Jalur dua $\mathrm{X}-\mathrm{Y}$

Tabel 5. Hasil Uji Glejser

\begin{tabular}{ccl}
\hline Variabel & Sig. & Keterangan \\
\hline Kecerdasan Emosional (X1) & 0,535 & Homokedastisitas \\
Komitmen Organisasional (X2) & 0,282 & Homokedastisitas \\
Organizational Citizenship Behavior (Z) & 0,123 & Homokedastisitas \\
\hline
\end{tabular}

Sumber: diolah, 2019

Berdasarkan tabel diatas dapat diketahui nilai signifikansi $(\alpha)$ masing- masing variabel memiliki nilai lebih dari (>) 0,05 sehingga dapat disimpulkan tidak terjadi heteroskedastisitas pada persamaan yang diuji.

\subsection{Pengujian Hipotesis}

\subsubsection{Uji t}

Uji t digunakan untuk menguji signifikansi konstanta dari setiap variabel independen, apakah variabel kecerdasan emosional (X1) dan komitmen organisasional (X2) benar-benar berpengaruh secara parsial (terpisah) terhadap variabel dependennya yaitu kinerja karyawan (Y). Hasil pengujian hipotesis ditampilkan dalam Tabel 6 berikut:

Tabel 6. Hasil Uji t

\begin{tabular}{ccc}
\hline Hipotesis & $\boldsymbol{\alpha}$ & Sig \\
\hline 1 & 0,05 & 0,006 \\
2 & 0,05 & 0,042 \\
3 & 0,05 & 0,007 \\
4 & 0,05 & 0,005 \\
5 & 0,05 & 0,037 \\
\hline Sumber: &
\end{tabular}

Sumber: diolah, 2019 
Uji t hipotesis pada Tabel 6 menunjukkan hasil sebagai berikut:

a. Pengaruh Kecerdasan Emosional terhadap Organizational Citizenship Behavior (OCB)

Tabel 6 menunjukkan bahwa tingkat signifikansi $(\alpha)$ dari variabel kecerdasan emosional $\left(\mathrm{X}_{1}\right)$ adalah $0,006<0,05$. Hal ini dapat diartikan bahwa kecerdasan emosional terbukti berpengaruh signifikan terhadap Organizational Citizenship Behavior (OCB) ( $\mathrm{H}_{1}$ diterima).

b. Pengaruh Komitmen Organisasional terhadap Organizational Citizenship Behavior (OCB)

Tabel 6 menggambarkan bahwa tingkat signifikansi $(\alpha)$ dari variabel komitmen organisasional $\left(\mathrm{X}_{2}\right)$ adalah $0,042<0,05$. Hal ini dapat diartikan bahwa komitmen organisasional terbukti berpengaruh signifikan terhadap Organizational Citizenship Behavior (OCB) $\left(\mathrm{H}_{2}\right.$ diterima).

c. Pengaruh Kecerdasan Emosional terhadap Kinerja Karyawan

Berdasarkan Tabel 6 dapat dilihat bahwa tingkat signifikansi $(\alpha)$ dari variabel kecerdasan emosional $\left(\mathrm{X}_{1}\right)$ adalah $0,007<0,05$. Hal ini dapat diartikan bahwa kecerdasan emosional terbukti berpengaruh signifikan terhadap kinerja karyawan $\left(\mathrm{H}_{3}\right.$ diterima).

d. Pengaruh Komitmen Organisasional terhadap Kinerja Karyawan

Tabel 6 dapat mendeskripsikan bahwa tingkat signifikansi $(\alpha)$ dari variabel komitmen organisasional $\left(\mathrm{X}_{2}\right)$ adalah $0,005<0,05$. Hal ini dapat diartikan bahwa komitmen organisasional terbukti berpengaruh signifikan terhadap kinerja karyawan $\left(\mathrm{H}_{4}\right.$ diterima).

e. Pengaruh Organizational Citizenship Behavior (OCB) terhadap Kinerja Karyawan

Tabel 6 dapat memberi pemahaman bahwa tingkat signifikansi $(\alpha)$ dari variabel Organizational Citizenship Behavior (OCB) (Z) adalah 0,037 < 0,05. Hal ini dapat diartikan bahwa Organizational Citizenship Behavior (OCB) terbukti berpengaruh signifikan terhadap kinerja karyawan $\left(\mathrm{H}_{5}\right.$ diterima).

\subsubsection{Analisis Jalur (Path Analysis)}

Analisis jalur akan digunakan untuk mengestimasi pengaruh kausal antara variabel dan kedudukan masing-masing variabel dalam jalur baik secara langsung maupun tidak langsung. Hasil analisis jalur dapat dilihat sebagai berikut:

Tabel 7. Hasil Uji Analisis Jalur

\begin{tabular}{ccccc}
\hline \multicolumn{2}{c}{ Standarized } & \multirow{2}{*}{ Sig. } & $\boldsymbol{\alpha}$ & \multirow{2}{*}{ Keterangan } \\
\cline { 1 - 2 } Jalur & Beta & & & \\
\cline { 1 - 2 } X1-Z & 0,209 & 0,006 & 0,05 & Signifikan \\
X2 - Z & 0,246 & 0,042 & 0,05 & Signifikan \\
X1-Y & 0,216 & 0,007 & 0,05 & Signifikan \\
X2-Y & 0,358 & 0,005 & 0,05 & Signifikan \\
Z-Y & 0,185 & 0,037 & 0,05 & Signifikan \\
\hline
\end{tabular}

Sumber: diolah, 2019 
Berdasarkan Tabel diatas, hasil analisis jalur pertama dapat dijelaskan bahwa antara Kecerdasan Emosional (X1) dengan Organizational Citizenship Behavior (OCB) (Z) memiliki pengaruh yang signifikan. Hal tersebut dapat diketahui dengan hasil nilai signifikasi yaitu 0,006 kurang dari $(<) \alpha=0,05$. Jalur kedua antara Komitmen Organisasional (X2) dengan Organizational Citizenship Behavior (OCB) (Z) memiliki pengaruh yang signifikan yaitu 0,042 kurang dari $(<) \alpha=0,05$. Jalur ketiga antara Kecerdasan Emosional (X1) dengan Kinerja Karyawan (Y) memiliki pengaruh yang signifikan yaitu 0,007 kurang dari $(<) \alpha=0,05$. Jalur keempat antara Komitmen Organisasional (X2) dengan Kinerja Karyawan (Y) memiliki pengaruh yang signifikan yaitu 0,005 kurang dari $(<) \alpha=0,05$. Jalur kelima antara Organizational Citizenship Behavior (OCB) (Z) dengan Kinerja Karyaan (Y) memiliki pengaruh yang signifikan yaitu 0,037 kurang dari $(<) \alpha=0,05$.

\subsubsection{Menghitung Jalur}

Perhitungan jalur ini menjelaskan tentang pengaruh kecerdasan emosional (X1) dan komitmen organisasional (X2) baik secara langsung maupun tidak langsung terhadap kinerja perusahaan (Y) melalui variabel Organizational Citizenship Behavior (OCB) (Z), hasil nya sebagai berikut:

a. Pengaruh Langsung (Direct Effect atau DE)

1) Pengaruh variabel kecerdasan emosional terhadap Organizational Citizenship Behavior (OCB) adalah sebesar 0,209 atau 20,9\%.

2) Pengaruh variabel komitmen organisasional terhadap Organizational Citizenship Behavior (OCB) adalah sebesar 0,246 atau 24,6\%.

3) Pengaruh variabel kecerdasan emosional terhadap kinerja karyawan adalah sebesar 0,216 atau 21,6\%.

4) Pengaruh variabel komitmen organisasional terhadap kinerja karyawan adalah sebesar 0,358 atau 35,8\%.

5) Pengaruh variabel Organizational Citizenship Behavior (OCB) terhadap kinerja karyawan adalah sebesar 0,185 atau $18,5 \%$

b. Pengaruh Tidak Langsung (Indirect Effect atau IE)

1) Pengaruh variabel kecerdasan emosional terhadap kinerja karyawan melalui Organizational Citizenship Behavior (OCB) adalah sebesar $(0,209 \times 0,185)=0,038$.

2) Pengaruh variabel komitmen organisasional terhadap kinerja karyawan melalui Organizational Citizenship Behavior (OCB) adalah sebesar $(0,246 \times 0,185)=0,045$.

c. Pengaruh Total

1) Total pengaruh $: X_{1} \rightarrow Z \rightarrow Y, 0,038+0,216=0,254$ atau $25,4 \%$

2) Total pengaruh $: X_{2} \rightarrow Z \rightarrow Y, 0,045+0,358=0,403$ atau $40,3 \%$

\section{HASIL DAN PEMBAHASAN}

\subsection{Pengaruh Kecerdasan Emosional Terhadap Organizational Citizenship Behavior (OCB)}

Berdasarkan hasil penelitian uji analisis data kecerdasan emosional para karyawan yang ada pada Roxy Square Mall Jember membuktikan bahwa terdapat pengaruh secara langsung, pengaruh tersebut memiliki pengaruh signifikan yang positif terhadap Organizational Citizenship Behavior (OCB). Hal ini dibuktikan dari 
hasil analisis jalur (path analysis) juga membuktikan pada uji t terhadap hipotesis pertama (H1) dapat dilihat pada hasil uji t yang menunjukkan bahwa kecerdasan emosional memiliki tingkat signifikansi sebesar 0,006 kurang dari tingkat signifikansi yang telah ditentukan yaitu 0,05 atau $5 \%$, artinya kecerdasan emosional berpengaruh signifikan terhadap Organizational Citizenship Behavior (OCB). Hubungan tersebut juga ditunjukkan oleh koefisien regresi positif dengan nilai $b=$ 0,209 yang merupakan besarnya kontribusi kecerdasan emosional yang mempengaruhi Organizational Citizenship Behavior (OCB). Hal tersebut menunjukkan bahwa semakin baik persepsi kecerdasan emosional maka perilaku Organizational Citizenship Behavior (OCB) akan dipersepsi semakin baik

Sesuai teori Goleman (2015) dalam mengukur tingkat kecerdasan emosional dengan membagi ke dalam berbagai dimensi meliputi pengenalan diri, regulasi diri, motivasi, empati dan keterampilan sosial dapat mendukung hasil penelitian ini, dikarenakan karyawan Roxy Square Mall Jember yang memiliki pengenalan diri yang baik akan menjadikan karyawan tersebut mampu mengenali karakteristik pada dirinya. Karyawan yang sudah kenal dengan karakteristik dirinya akan memunculkan rasa percaya terhadap dirinya, sehingga mampu menimbulkan motivasi dalam diri karyawan. Hal itu dapat mempermudah karyawan dalam menyesuaikan diri terhadap semua tipe karyawan yang ada pada perusahaan, alhasil interaksi hubungan antar karyawan akan semakin baik yang berdampak pada hubungan kerja yang lebih baik antar karyawan dan juga antar karyawan dengan perusahaan. Situasi tersebut membuat hubungan batin karyawan lebih erat, sehingga rasa toleransi maupun saling tolong-menolong antar karyawan akan mudah tercapai. Hasilnya karyawan akan memiliki prilaku Organizational Citizenship Behavior (OCB) pada setiap diri mereka. Jika hal-hal tersebut dapat selalu diterapkan oleh setiap karyawan maka perilaku Organizational Citizenship Behavior (OCB) yang tinggi dapat mudah tercapai.

Hasil penelitian ini sekaligus menjawab rumusan masalah bagaimana kecerdasan emosional dapat berpengaruh terhadap Organizational Citizenship Behavior (OCB) pada karyawan. Hasil penelitian ini juga selaras dengan penelitian Sumyarsih et al. (2012) yang menunjukan hasil kecerdasan emosional karyawan berpengaruh signifikan positif terhadap perilaku Organizational Citizenship Behavior (OCB) pada karyawan.

\subsection{Pengaruh Komitmen Organisasional Terhadap Organizational Citizenship Behavior (OCB)}

Berdasarkan hasil penelitian komitmen organisasional pada karyawan Roxy Square Mall Jember membuktikan bahwa terdapat pengaruh langsung terhadap perilaku Organizational Citizenship Behavior (OCB) pada karyawan. Hal ini dibuktikan dari hasil analisis jalur (path analysis) juga membuktikan pada uji $\mathrm{t}$ terhadap hipotesis kedua $(\mathrm{H} 2)$ dapat dilihat pada hasil uji t yang menunjukkan bahwa komitmen organisasional memiliki tingkat signifikansi sebesar 0,042 kurang dari tingkat signifikansi yang telah ditentukan yaitu 0,05 atau 5\%, artinya komitmen organisasional berpengaruh signifikan terhadap Organizational Citizenship Behavior (OCB). Pengaruh tersebut memiliki nilai signifikan yang positif terhadap perilaku Organizational Citizenship Behavior (OCB) pada karyawan. Hubungan tersebut juga ditunjukkan oleh koefisien regresi positif dengan nilai $b=0,246$ yang merupakan besarnya komitmen organisasional yang mempengaruhi Organizational Citizenship 
Behavior (OCB). Hal tersebut menunjukkan bahwa semakin baik persepsi komitmen organisasional maka perilaku Organizational Citizenship Behavior (OCB) akan dipersepsi semakin baik.

Hasil penelitian ini sejalan dengan Putrana et al. (2016) yang membuktikan adanya pengaruh positif dan signifikan antara variabel komitmen organisasional terhadap Organizational Citizenship Behavior (OCB). Menurut Kreutner dan Kinicki $(2014,165)$ komitmen organisasional sebagai tingkatan seseorang dalam mengenali sebuah organisasi dan juga terkait pada tujuan-tujuan organisasi. Hal ini dikerucutkan oleh Edison et al. (2016, 220) dengan mengartikan komitmen karyawan sebagai suatu bentuk dimana karyawan memiliki keterlibatan, menerima kondisi lingkungan yang ada, serta berusaha untuk berprestasi dan mengabdi. Berangkat dari teori tersebut karyawan Roxy Square Mall Jember akan dapat berperilaku Organizational Citizenship Behavior (OCB) dengan tinggi, jika dalam diri mereka memiliki keinginan atau motivasi yang tinggi terhadap upaya yang keras terhadap pencapaian tujuan perusahaan. Rasa keinginan dan motivasi ini timbul atas dasar memiliki kesatuan antar karyawan dengan tujuan dan nilai-nilai perusahaan. Atas dasar ini karyawan akan berkeinginan untuk tetap berada pada perusahaan, yang imbasnya pada kesediaan untuk bekerja lebih keras atas nama perusahaan. Jika segala faktor mengenai komitmen organisasional tersebut dapat terus diadopsi dengan baik maka perilaku Organizational Citizenship Behavior (OCB) dapat tercipta dengan baik pada setiap karyawan.

Hasil penelitian ini sekaligus menjawab rumusan masalah bagaimana komitmen organisasional dapat berpengaruh terhadap Organizational Citizenship Behavior (OCB).

\subsection{Pengaruh Kecerdasan Emosional Terhadap Kinerja Karyawan}

Hasil dari penelitian pada kecerdasan emosional menunjukkan bahwa hasil analisis jalur (path analysis) juga membuktikan pada uji t terhadap hipotesis ketiga (H3) dapat dilihat pada hasil uji t yang menunjukkan bahwa kecerdasan emosional memiliki tingkat signifikansi sebesar 0,007 kurang dari tingkat signifikansi yang telah ditentukan yaitu 0,05 atau $5 \%$, artinya kecerdasan emosional berpengaruh signifikan terhadap kinerja karyawan. Hubungan tersebut juga ditunjukkan oleh koefisien regresi positif dengan nilai $b=0,216$ yang merupakan besarnya kontribusi kecerdasan emosional yang mempengaruhi kinerja karyawan. Hal tersebut menunjukkan bahwa semakin baik persepsi kecerdasan emosional maka kinerja karyawan akan semakin meningkat. Besarnya koefisien pengaruh tidak langsung kecerdasan emosional melalui Organizational Citizenship Behavior (OCB) terhadap kinerja sebesar 0,038 atau 3,8\% sedangkan pengaruh totalnya sebesar 0,254 atau $25,4 \%$. Nilai total pengaruh tidak langsung lebih kecil dibandingkan dengan pengaruh langsung, artinya variabel mediasi Organizational Citizenship Behavior (OCB) kurang berperan dalam meningkatkan kinerja karyawan Roxy Square Mall Jember.

Hasil pengaruh kecerdasan emosional terhadap kinerja karyawan, sejalan dengan teori yang dikemukakan oleh Prawironegoro dan Utari (2016, 98), yang mendefinisikan kecerdasan emosional sebagai kecerdasan perasaan (penghayatan) atau kepekaan, kelembutan, kehalusan perasaan, dan kecerdasan ini merupakan hasil dari hidup untuk bekerja dan berjuang meningkatkan dan memperbaiki hidup. Teori ini menjelaskan bahwa ada hubungan keterkaitan antara kecerdasan emosional 
seseorang terhadap kinerja yang diberikan oleh karyawan. Hasil penelitian Goleman (2015:44) memperkuat dengan memberi kesimpulan bahwa kecerdasan emosional menyumbang $80 \%$ dari faktor penentu kesuksesan seseorang. Dengan demikian kesuksesan dalam kinerja karyawan dapat dikatakan hasil sumbangan terbesar dari kecerdasan emosional karyawan tersebut.

Karyawan Roxy Square Mall Jember yang memiliki kemampuan untuk mengenali diriya, mengatur emosi pada dirinya, sehingga dapat memotivasi dirinya sendiri, serta mampu beradaptasi dengan lingkungan akan dapat mempermudah bagi karyawan untuk bekerja dengan baik. Hal ini dikarenakan karyawan yang memiliki kecerdasan emosional yang kuat akan lebih bisa mengenali karakter pada dirinya, sehingga membuat karyawaan lebih mudah dalam pengambilan keputusan pada setiap kinerjanya. Kemudahan dalam pengambilan keputusan ini akan lebih mengoptimalkan karyawan dalam bekerja, dengan demikian kinerja yang ditampilkan akan lebih baik. Jika hal-hal tersebut dapat selalu diterapkan oleh setiap karyawan maka kinerja yang baik dapat mudah tercapai. Hasil penelitian ini juga sejalan dengan penelitian Fitriastuti (2013), Marga (2016), Pratama (2016), Amalia dan Purnawa (2016), dan Ardiansyah dan Sulistiyowati (2017) yang menunjukan hasil bahwa kecerdasan emosional berpengaruh signifikan positif terhadap kinerja karyawan. Hasil penelitian ini sekaligus menjawab rumusan masalah bagaimana kecerdasan emosional dapat berpengaruh terhadap kinerja karyawan.

\subsection{Pengaruh Komitmen Organisasional Terhadap Kinerja Karyawan}

Berdasarkan hasil penelitian pada komitmen organisasional para karyawan yang ada pada Roxy Square Mall Jember membuktikan bahwa terdapat pengaruh secara langsung, pengaruh tersebut memiliki pengaruh signifikan yang positif terhadap kinerja karyawan. Hal ini dibuktikan dari hasil analisis jalur (path analysis) juga membuktikan pada uji t terhadap hipotesis keempat (H4) dapat dilihat pada hasil uji t yang menunjukkan bahwa komitmen organisasional memiliki tingkat signifikansi sebesar 0,005 kurang dari tingkat signifikansi yang telah ditentukan yaitu 0,05 atau 5\%, artinya komitmen organisasional berpengaruh signifikan terhadap kinerja karyawan. Hubungan tersebut juga ditunjukkan oleh koefisien regresi positif dengan nilai $b=0,358$ yang merupakan besarnya kontribusi komitmen organisasional yang mempengaruhi kinerja karyawan. Hal tersebut menunjukkan bahwa semakin baik persepsi komitmen organisasional maka kinerja karyawan akan semakin meningkat. Besarnya koefisien pengaruh tidak langsung komitmen organisasional melalui Organizational Citizenship Behavior (OCB) terhadap kinerja sebesar 0,045 atau 4,5\% sedangkan pengaruh totalnya sebesar 0,403 atau 40,3\%. Nilai total pengaruh tidak langsung lebih kecil dibandingkan dengan pengaruh langsung, artinya variabel mediasi Organizational Citizenship Behavior (OCB) kurang berperan dalam meningkatkan kinerja karyawan Roxy Square Mall Jember.

Hasil pengaruh komitmen organisasional terhadap kinerja karyawan, selaras dengan teori Robbins dan Judge $(2016,110)$ yang mengatakan bahwa komitmen organisasional sebagai suatu keadaan seseorang karyawan yang memihak kepada perusahaan dan tujuan-tujuannya serta berniat untuk memelihara keanggotaan dalam perusahaan tersebut. Yulinarti dan Dania (2020) menyimpulkan bahwa sikap memihak karyawan kepada perusahaan dan juga terhadap tujuan-tujuan perusahaan serta berusaha loyal terhadap perusahaan akan memberikan dampak pada kinerja karyawan tersebut. Karyawan Roxy Square Mall Jember yang memiliki rasa 
keselarasan terhadap tujuan perusahaan dan nilai-nilai pada perusahaan akan mengantarkan karyawan pada keinginan untuk tetap setia terhadap perusahaan, dengan rasa kesetiaan terhadap perusahaan akan mempermudah karyawan dalam bekerja dengan baik. Hal ini dikarenakan nilai-nilai yang terkandung pada perusahaan sudah diterima oleh karyawan dan karyawan merasa bahwa nilai-nilai tersebut dirasa cocok dengan nilai yang ada pada karyawan. Sehingga karyawan Roxy Square Mall dalam bekerja akan selalu pada jalur nilai-nilai perusahaan yang hasilnya kinerja karyawan akan sesuai dengan harapan perusahaan. Hasil penelitian ini juga sejalan dengan penelitian Jatmiko et al. (2015), Respatiningsih dan Sudirjo (2015), Putrana et al. (2016), Damaryanthi dan Dewi (2016), Sapitri (2016), dan Akbar et al. (2017) yang menunjukan hasil bahwa komitmen organisasional berpengaruh signifikan positif terhadap kinerja karyawan. Hasil penelitian ini sekaligus menjawab rumusan masalah bagaimana komitmen organisasional dapat berpengaruh terhadap kinerja karyawan.

\subsection{Pengaruh Organizational Citizenship Behavior (OCB) Terhadap Kinerja Karyawan}

Berdasarkan hasil penelitian pada perilaku Organizational Citizenship Behavior (OCB) para karyawan yang ada pada Roxy Square Mall Jember membuktikan bahwa terdapat pengaruh secara langsung, pengaruh tersebut memiliki pengaruh signifikan yang positif terhadap kinerja karyawan. Hal ini dibuktikan dari hasil analisis jalur (path analysis) juga membuktikan pada uji t terhadap hipotesis kelima (H5) dapat dilihat pada hasil uji t yang menunjukkan bahwa Organizational Citizenship Behavior (OCB) memiliki tingkat signifikansi sebesar 0,037 kurang dari tingkat signifikansi yang telah ditentukan yaitu 0,05 atau 5\%, artinya Organizational Citizenship Behavior (OCB) berpengaruh signifikan terhadap kinerja karyawan. Hubungan tersebut juga ditunjukkan oleh koefisien regresi positif dengan nilai $\mathrm{b}=$ 0,185 yang merupakan besarnya kontribusi Organizational Citizenship Behavior (OCB) yang mempengaruhi kinerja karyawan. Hal tersebut menunjukkan bahwa semakin baik persepsi Organizational Citizenship Behavior (OCB) maka kinerja karyawan akan semakin meningkat.

Hal ini sejalan dengan teori Organ yang menyatakan bahwa Organizational Citizenship Behavior (OCB) sebgai perilaku individu yang ekstra, yang tidak secara langsung atau eksplisit dapat dikenali dalam suatu sistem kerja yang formal, dan yang secara agregat mampu meningkatkan efektivitas fungsi organisasi. Sejalan dengan terori tersebut Purnamie (2014:5) juga memperkuat dengan mendefinisikan Organizational Citizenship Behavior (OCB) sebagai kontribusi karyawan yang melebihi tuntutan peran ditempat kerja. Perilaku ini dapat dikenali dengan melihat perilaku karyawan saling tolong menolong antar karyawan, bekerja melebihi tugas yang dibebankan, bersikap toleransi terhadap sesama dan menjaga hubungan baik antar karyawan serta dapat bertannggung jawab atas segala kinerjanya. Karyawan Roxy Square Mall Jember yang memiliki perilaku Organizational Citizenship Behavior (OCB) akan mempermudah karyawan dalam bekerja dengan baik. Hal ini dikarenakan dengan adanya perilaku tersebut akan memberikan rasa nyaman bagi karyawan dalam bekerja, sebab perilaku saling tolong menolong dalam bekerja akan memberi daya positif pada setiap karyawan. Situasi tersebut dapat menciptakan rasa toleransi antar karyawan menjadi lebih baik sehingga hubungan antar karyawan semakin dekat dan erat. Dampak dari situasi tersebut karyawan merasa nyaman, yang 
imbasnya karyawan akan bekerja melebihi beban kerja yang diberikan oleh perusahaan, alhasil kinerja yang dihasilkan karyawan akan semakin baik. Hasil penelitian ini juga sejalan dengan penelitian oleh Kimbal et al. (2015), Suzana (2017), Pristiwati dan Suharyono (2018) serta Ramadhan et al. (2018) yang menunjukan hasil bahwa Organizational Citizenship Behavior (OCB) berpengaruh signifikan positif terhadap kinerja karyawan. Hasil penelitian ini sekaligus menjawab rumusan masalah bagaimana Organizational Citizenship Behavior (OCB) dapat berpengaruh terhadap kinerja karyawan.

\section{KESIMPULAN}

Berdasarkan hasil analisis dan pembahasan yang telah peneliti jelaskan maka dapat disimpulkan sebagai berikut:

a. Kecerdasan Emosional berpengaruh positif dan signifikan terhadap Organizational Citizenship Behavior (OCB) pada karyawan Roxy Square Mall Jember. Hal ini berarti bahwa semakin karyawan memiliki kecerdasan emosional dalam mengenali dirinya, mengontrol dirinya, memotivasi dirinya, berempati terhadap sesama serta mampu berhubungan baik dengan sesama, maka kecerdasan emosional yang sudah diterapkan dan dipersepsi baik oleh karyawan akan meningkatkan perilaku Organizational Citizenship Behavior (OCB) yang dirasakan oleh karyawan selama bekerja di dalam perusahaan.

b. Komitmen Organisasional berpengaruh positif dan signifikan terhadap Organizational Citizenship Behavior (OCB) pada karyawan Roxy Square Mall Jember. Hal ini berarti semakin karyawan memiliki rasa kesatuan terhadap tujuan dan nilai-nilai perusahaan, keinginan untuk tetap berada ada perusahaan serta bersedia bekerja keras atas nama perusahaan, maka komitmen organisasional yang sudah diterapkan dan dipersepsi baik oleh karyawan akan meningkatkan perilaku Organizational Citizenship Behavior (OCB) pada setiap karyawan.

c. Kecerdasan Emosional berpengaruh positif dan signifikan terhadap Kinerja Karyawan pada Roxy Square Mall Jember. Hal ini berarti semakin karyawan memiliki kecerdasan emosional dalam hal mengenali dirinya, mampu mengontrol emosi pada dirinya, dapat memotivasi diri, serta aktif berhubungan dengan sesama karyawan dengan baik, maka kecerdasan emosional yang sudah diterapkan dan dipersepsi baik oleh karyawan akan meningkatkan kinerja karyawan lebih baik.

d. Komitmen Organisasional berpengaruh positif dan signifikan terhadap Kinerja Karyawan pada Roxy Square Mall Jember. Hal ini berarti semakin karyawan merasa bahwa dirinya telah menerima tujuan dan nilai-nilai yang ada di perusahaan serta keinginan yang kuat untuk tetap setia pada perusahaan, maka komitmen organisasional yang sudah diterapkan dan dipersepsi baik oleh karyawan akan meningkatkan kinerja karyawan menjadi lebih baik.

e. Organizational Citizenship Behavior (OCB) berpengaruh positif dan signifikan terhadap Kinerja Karyawan. Hal ini dapat diartikan bahwa semakin baik karyawan memiliki perilaku saling tolong-menolong, bekerja melebihi tugas yang diberikan, menjaga hubungan baik antar sesama serta bertanggung jawab terhadap pekerjaannya, maka perilaku Organizational 
Citizenship Behavior (OCB) yang sudah diterapkan dan dipersepsi baik oleh karyawan akan meningkatkan kinerja karyawan menjadi semakin baik.

f. Kecerdasan Emosional dan Komitmen Organisasional berpengaruh tidak langsung terhadap Kinerja Karyawan melalui Organizational Citizenship Behavior (OCB). Apabila dianalisis lebih lanjut, presentase pengaruh tidak langsung lebih kecil dibandingkan pengaruh langsung. Hal ini menunjukkan bahwa variabel mediasi Organizational Citizenship Behavior (OCB) kurang berperan pengaruhnya terhadap kinerja karyawan.

\section{DAFTAR PUSTAKA}

Akbar, A., M. A. Musadieq, dan M. D. Mukzam. 2017. Pengaruh Komitmen Organisasional Terhadap Kinerja (Studi Pada Karyawan PT Pelindo Surabaya). Jurnal Administrasi dan Bisnis (JAB) 47 (2):33-38.

Amalia, S., dan R. Purnawa. 2016. Pengaruh Kecerdasan Emosional Terhadap Kinerja Pegawai PT Indonesia Comnets Plus di Bandung. Journal of Business Management and Enterpreneurship Education 1 (1):24-30.

Ardiansyah, Y., dan L. H. Sulistiyowati. 2017. Pengaruh Kompetensi dan Kecerdasan Emosional Terhadap Kinerja Pegawai. Jurnal Insipirasi Bisnis dan Manajemen 2 (1):91-100.

Damaryanthi, A. A. I., dan A. A. S. K. Dewi. 2016. Pengaruh Kecerdasan Emosional, Komitmen Organisasi, dan Organizational Citizenship Behavior Terhadap Kinerja Pegawai FEB. E-Jurnal Manajemen Unud, 5 (2):790-820.

Edison, E., Y. Anwar, dan Komariah. 2016. Manajemen Sumber Daya Manusia. Bandung: Alfabeta.

Fitriastuti, T. 2013. Pengaruh Kecerdasan Emosional, Komitmen Organisasional dan Organizational Citizenship Behavior terhadap Kinerja Karyawan. Jurnal Dinamika Manajemen 4 (2):103-114.

Garay, H. D. V. 2006. Kinerja Extra-Role dan Kebijakan Kompensas. SINERGI, Kajian Bisnis Dan Manajemen 8 (1):33-42.

Goleman, D. 2015. Kecerdasan Emosional; Mengapa Emotional Intellegence Lebih tinggi dari IQ. Jakarta: PT. Gramedia Pustaka Utama.

Jatmiko, E. D., B. Swasto, dan G. Eko. 2015. Pengaruh Motivasi Kerja dan Komitmen Organisasional Terhadap Kinerja Karyawan (Studi Pada Karyawan Kompartemen Pabrik II PT. Petrokimia Gresik). Jurnal Administrasi dan Bisnis (JAB) 21 (1):1-8.

Kimbal, F. F. M., G. M. Sendow, dan D. j. Adare. 2015. Pengaruh Beban Kerja, Organizational Citizenship Behavior dan Keterlibatan Kerja Pengaruhnya Terhadap Kinerja Karyawan PT. PLN (Persero)Wilayah Suluttenggo Area Manado. Jurnal EMBA: Ekonomi, Manajemen, Bisnis, dan Akuntansi 3 (2):1061-1072.

Kreutner, K., dan A. Kinicki. 2014. Perilaku Organisasional. edited by E. 9. Jakarta: Penebit Salemba Empat.

Kurniawan, A. 2015. Pengaruh Komitmen Organisasi Terhadap Organizational Citizenship Behavior (OCB) PT X Bandung. Jurnal Manajemen 15 (1):95118. 
Marga, Y. K. 2016. Pengaruh Pelatihan, Kecerdasan Emosional dan Budaya Organisasi Terhadap Kinerja Karyawan Pada PT. Pelayaran Tempuran Emas Surabaya. E-Jurnal Manajemen Kinerja 2 (1).

Pratama, F. 2016. Pengaruh Kecerdasan Emosional Terhadap Kinerja Karyawan Melalui Organizational Citizenship Behavior Pada Perusahaan Bersatu Sukses Group Surabaya. Jurnal Ilmu Manajemen 2 (2).

Prawironegoro, D., dan D. Utari. 2016. Manajemen SDM Abad 21. Jakarta: Mitra Wacana Media.

Pristiwati, M., dan B. S. Suharyono. 2018. Pengaruh Komitmen Organisasional dan Organizational Citizenship Behavior Terhadap Kinerja Karyawan (Studi Pada Karyawan PT PLN (Persero) Area Sidoarjo). Jurnal Administrasi dan Bisnis (JAB) 61 (4):159-168.

Putrana, Y., A. Fathoni, dan M. M. Warso. 2016. Pengaruh Kepuasan Kerja dan Komitmen Organisasi Terhadap Organizational Citizenship Behavior Dalam Meningkatkan Kinerja Karyawan Pada PT. Gelora Persada Mediatama Semarang. . Journal Of Management 2 (2).

Ramadhan, F. P., H. Susilo, dan E. K. Aini. 2018. Pengaruh Organizational Citizenship Behavior (OCB) dan Good Corporate Governance (GCD) Terhadap Kinerja Karyawan (Studi pada Karyawan PT. TASPEN (Persero) Kantor Cabang Malang). Jurnal Administrasi dan Bisnis (JAB) 55 (2):160166.

Respatiningsih, I., dan F. Sudirjo. 2015. Pengaruh Komitmen Organisasi, Motivasi, Kapabilitas dan Kepuasan Kerja Terhadap Kinerja Pegawai (Studi Empirik Pada Inspektorat Kabupaten Pemalang). Jurnal Ilmiah UNTAG 4:56-68.

Robbins, S. P., dan T. A. Judge. 2016. Perilaku Organisasi. Jakarta: Penerbit Salemba Empat.

Rochayatun, S., dan M. F. Setiawan. 2020. Effect of Commitment, Motivation and Feedback to Job Performance. Journal of Contemporary Information Technology, Management, and Accounting 1 (1):9-17.

Sapitri, R. 2016. Pengaruh Komitmen Organisasi Terhadap Kinerja Karyawan Perusahaan Listrik Negara Area Pekan Baru. JOM Fisip 3 (2).

Sumyarsih, W., E. Mujiasih, dan J. Ariati. 2012. Hubungan Antara Kecerdasan Emosional dengan Organizational Citizenship Behavior (OCB) pada Karyawan CV Aneka Ilmu Semarang. Jurnal Psikologi Universitas Diponegoro 11 (1):19-27.

Suzana, A. 2017. Pengaruh Organizational Citizenship Behavior (OCB) Terhadap Kinerja Karyawan (Studi di PT. Taspen (Persero) Kantor Cabang Cirebon). . Jurnal Logika 19 (1).

Yulinarti, dan E. W. Dania. 2020. Organizational Culture, Job Satisfaction, adan Employee Perfomance (Case Study in PT GMT Jember). Journal of Contemporary Information Technology, Management, and Accounting 1 (1):28-38. 